\section{Cranberry Tolerance to Clopyralid}

\author{
Kim Patten ${ }^{1}$ and John Wang ${ }^{2}$ \\ Washington State University, Long Beach Research and Extension Unit, Box \\ 570, Long Beach, WA 98631
}

Fred Katz ${ }^{3}$ and Don Riemer ${ }^{4}$

Plant Science Department, Cook College, Rutgers State University of New

Jersey, P.O. Box 231, New Brunswick, NJ 08903-0231

Chuck Kusek $^{5}$

Ocean Spray Cranberries, 1 Ocean Spray Drive, Lakeville-Middleboro, MA 02349

\author{
Herb Hopen ${ }^{4}$ \\ Department of Horticulture, University of Wisconsin, Madison, WI 53706
}

Additional index words. Vaccinium macrocarpon

\begin{abstract}
Tolerance of cranberry (Vaccinium macrocarpon Ait.) at different phenological stages to the postemergent broadleaf herbicide clopyralid $(0.21$ or $0.42 \mathrm{~kg}$ a.i./ha) was evaluated in Washington, New Jersey, Massachusetts, and Wisconsin. Tolerance varied among states, rates, and application times. Applications made during early shoot growth, especially at the high rate, usually resulted in the most crop injury (leaf cupping and epinasty and reduced yield); while applications at the low rate made after vegetative development occurred usually resulted in less or no injury. No phytotoxicity occurred when applications were made before shoot growth (Washington and New Jersey). Chemical name used: 3,6-dichloro-2-pyridinecarboxylic acid (clopyralid).
\end{abstract}

Broadleaf weed (Vaccinium macrocarpon Ait.) control in cranberry plantings requires applying postemergence herbicides, but there are none registered for broadcast use on cranberries. Clopyralid is a systemic postemergence herbicide with auxin-like activity for use in selective control of weeds in the Leguminosae and Compositae families (Weed Science Society of America, 1989). Clopyralid controls several troublesome weeds in cranberry bogs (Devlin and Zbiec, 1992). Crop injury, however, has been inconsistent, ranging from minor with a single application after fruit set to severe with a prebloom or double application (Devlin and Zbiec, 1992; Patten et al., 1991). Crop injury likely resulted from excessive rates used $(>0.42 \mathrm{~kg}$ a.i./ha), split applications, or inappropriate application times. Our objective was to evaluate the phytotoxicity of low clopyralid rates on cranberries at various development stages for each of the major growing regions.

Received for publication 13 Dec. 1993. Accepted for publication 4 June 1994. H/LA Paper no. 93-25. Project no. 6090, College of Agriculture and Home Economics Research Center, Washington State Univ., Pullman. The cost of publishing this paper was defrayed in part by the payment of page charges. Under postal regulations, this paper therefore must be hereby marked advertisement solely to indicate this fact.

${ }^{1}$ Associate Horticulturist.

${ }^{2}$ Research Technician.

${ }^{3}$ Graduate Student.

${ }^{4}$ Professor.

${ }^{5}$ Cranberry Scientist.

\section{Materials and Methods}

Cranberry bogs with a uniform upright density and low weed populations were selected in Long Beach, Wash. ('Early Black'); Chatsworth, N.J. ('Early Black'); South Carver, Mass. ('McFarlin'); and Warrens, Wis. ('Searles'). For all states, clopyralid was broadcast with a $\mathrm{CO}_{2}$ sprayer at 0.21 or $0.42 \mathrm{~kg}$ a.i./ ha at prebloom or bloom or after fruit set. In all states, except Wisconsin, $0.42 \mathrm{~kg}$ a.i./ha was applied as a prebloom spray, followed with $0.21 \mathrm{~kg}$ a.i./ha applied at bloom or after fruit set. A 0.21 - and $0.42-\mathrm{kg}$ a.i./ha treatment also was applied in Washington and New Jersey at early budbreak and early vegetative growth, respectively. The design was a randomized complete block with five replications in Washington and New Jersey and four and two replications in Massachusetts and Wisconsin, respectively. Plot size was $1 \times 2.5,2.2 \times 6.2,1.5$ $\times 1.5,0.9 \times 2.8 \mathrm{~m}$ for Washington, New Jersey, Massachusetts, and Wisconsin, respectively. Plots were rated visually for phytotoxicity (leaf cupping, epinasty, and necrosis) during late summer in the treatment year and sampled for yield in the treatment year and the following year. Yield was determined from a subsample collected from within each plot. Fruit set and mean fruit size were determined at some sites. Data from each site were analyzed separately by analysis of variance and treatments were compared to the control by Dunnett's $t$ test (SAS Institute, 1985).

\section{Results and Discussion}

The level of crop injury and yield suppression resulting from clopyralid treatment var- ied among states, application rates, and application time (Table 1). In Washington, the budbreak application induced no phytotoxicity, and the postbloom, high-rate application caused the most damage. In all cases, however, injury was minor and did not reduce fruit set (data not shown) or yield in the year of application. In the year following application, yield was lowest for the high rate applied during bloom and highest for the low rate applied in August. In New Jersey, noticeable phytotoxicity (decreased leaf size, reduction in internode length, and epinasty) was evident 2 weeks after clopyralid treatment, especially with early applications. By the end of the growing season, symptoms were no longer visible in any prebloom treatments but were still pronounced in the split applications, the high rate during bloom, and the postbloom treatments. Yield in the treatment year was reduced by a high clopyralid rate applied in early May, especially when combined with an additional spray during bloom. This split application was the only treatment that markedly reduced fruit size (data not shown). In the following year, yield was suppressed in plants treated during bloom or fruit set, or with split applications. In Massachusetts, split applications increased phytotoxicity. Prebloom applications or applications split between prebloom and bloom or after fruit set reduced fruit set (data not shown) and yield in the year of treatment. Clopyralid did not reduce fruit size (data not shown). July clopyralid applications at the low rate did not injure cranberry plants or reduce yield. In the year following treatment, yield was reduced by all treatments except the low rate applied at bloom or fruit set. In Wisconsin, inadequate replications made reliable inferences impossible.

Although data were not consistent among growing regions, several trends were apparent: 1) phytotoxicity of clopyralid appears to parallel the level of vegetative meristematic activity. Application during early shoot growth induced the most injury. Much of the inconsistency among growing regions may be related to differences in vegetative activity or phenology at similar application dates. If applications were made at low rates before early shoot development (early May treatment in Washington) or after major vegetative growth (late July in New Jersey, Massachusetts, and Wisconsin), phytotoxicity symptoms tended to be minor. 2) The 0.21-kg a.i./ha rate induced less injury than the higher rates or sequential applications of both rates. 3) Even in cases of major crop injury, the results were usually only transitory and in no instance was there a total crop loss. Where excessively high rates (two applications of $0.84 \mathrm{~kg}$ a.i./ha) were applied and total crop loss occurred, plants recovered in 2 years (Patten et al., 1991).

Cranberry tolerance to clopyralid during periods of reduced meristematic activity suggests that either absorption or transport may be affected or that actively dividing cells are most susceptible. The cuticle is the major barrier preventing the penetration and diffusion of weakly acidic herbicides into the apoplast (Kloppenburg and Hall, 1990). Thus, toler- 
Table 1. Cranberry phytotoxicity and yield in Washington, New Jersey, Massachusetts, and Wisconsin as affected by application rate and timing of clopyralid. ${ }^{2}$

\begin{tabular}{|c|c|c|c|c|c|c|c|c|c|c|c|c|c|}
\hline \multirow{3}{*}{$\begin{array}{l}\text { Rate } \\
\text { (kg a.i./ha) }\end{array}$} & \multirow{3}{*}{$\begin{array}{l}\text { Application } \\
\text { time }^{w}\end{array}$} & \multicolumn{4}{|c|}{ Phytotoxicity rating ${ }^{y}$} & \multicolumn{8}{|c|}{ Yield $\left(\mathrm{Mg} \cdot h \mathrm{~h}^{-1}\right)^{\mathrm{x}}$} \\
\hline & & \multirow{2}{*}{$\begin{array}{l}\text { Wash- } \\
\text { ington }\end{array}$} & \multirow{2}{*}{$\begin{array}{l}\text { New } \\
\text { Jesey }\end{array}$} & \multirow{2}{*}{$\begin{array}{l}\text { Massa- } \\
\text { chusetts }\end{array}$} & \multirow{2}{*}{$\begin{array}{l}\text { Wis- } \\
\text { consin }\end{array}$} & \multicolumn{2}{|c|}{ Washington } & \multicolumn{2}{|c|}{ New Jersey } & \multicolumn{2}{|c|}{ Massachusetts } & \multicolumn{2}{|c|}{ Wisconsin } \\
\hline & & & & & & 1991 & 1992 & 1991 & 1992 & 1991 & 1992 & 1992 & 1993 \\
\hline$\overline{0}$ & & 0.4 & 0 & 0 & 1.0 & 8.4 & 21.7 & 9.1 & 15.2 & 23.8 & 21.8 & 7.4 & 9.0 \\
\hline 0.21 & Early vegetative & 0.6 & 0.2 & --- & --- & 9.1 & 24.1 & 8.2 & 11.2 & --- & --- & --- & --- \\
\hline 0.42 & Early vegetative & 0.8 & 0.2 & --- & --- & 7.4 & 25.7 & 4.5 & 12.5 & --- & --- & --- & --- \\
\hline 0.21 & Prebloom & $2.2^{*}$ & 0.4 & 2.0 & 2.0 & 8.3 & 19.8 & 9.3 & 11.3 & $8.3^{*}$ & $14.6^{*}$ & 2.1 & 3.1 \\
\hline 0.42 & Prebloom & $2.2^{*}$ & 0.2 & 2.0 & 2.5 & 9.3 & 16.2 & 8.4 & 12.4 & $4.5^{*}$ & $12.9^{*}$ & 3.7 & 1.6 \\
\hline 0.21 & Bloom & 1.4 & 1.0 & 0.7 & 2.5 & 11.1 & 22.9 & 10.1 & $5.3^{*}$ & 15.6 & 17.8 & 14.2 & 3.1 \\
\hline 0.42 & Bloom & 1.4 & $1.9^{*}$ & 0.7 & 2.5 & 8.8 & 16.2 & 7.0 & $5.7^{*}$ & 11.2 & 15.9 & 7.3 & 2.5 \\
\hline 0.21 & Fruit set & 1.4 & $1.6^{*}$ & 0.5 & 1.5 & 6.0 & 28.7 & 10.0 & $4.7^{*}$ & 20.3 & 21.1 & 16.3 & 5.5 \\
\hline 0.42 & Fruit set & $3.2^{*}$ & $2.5^{*}$ & 0.5 & 1.5 & 10.8 & 18.9 & 9.6 & $7.5^{*}$ & $16.5^{*}$ & $13.7^{*}$ & 15.7 & 2.9 \\
\hline 0.42 & Prebloom & 1.4 & $1.9^{*}$ & $4.5^{*}$ & --- & 11.8 & 26.9 & $3.0^{*}$ & $8.1^{*}$ & $5.3^{*}$ & $9.9^{*}$ & --- & --- \\
\hline 0.21 & Bloom & & & & & & & & & & & & \\
\hline 0.42 & Prebloom & 1.4 & $4.4^{*}$ & $4.4^{*}$ & --- & 9.2 & 23.6 & 4.5 & $4.0^{*}$ & $3.7^{*}$ & $5.0^{*}$ & --- & --- \\
\hline 0.21 & Fruit set & & & & & & & & & & & & \\
\hline
\end{tabular}

${ }^{2}$ Treatments were applied in 1991 for Washington, New Jersey, and Massachusetts and 1992 for Wisconsin.

y Phytotoxicity ratings for Washington, New Jersey, and Massachusetts were $0=$ no damage to $10=$ dead. Ratings for Wisconsin were $1=$ no injury to $3=$ severe cranberry epinasty.

${ }^{x}$ Sample size for yield collection was $1.8 \mathrm{~m}^{2}$ in 1991 and $0.12 \mathrm{~m}^{2}$ in 1992 for Washington, $0.125 \mathrm{~m}^{2}$ for New Jersey, $0.09 \mathrm{~m}^{2}$ for Massachusetts and Wisconsin. ${ }^{\mathrm{w}}$ Cranberry phenology at application varied slightly by state. Treatments were applied at the following phenological stages: Washington, budbreak, 1- to 2-cm shoot growth, $5 \%$ bloom, and fruit set; New Jersey, $0.5-\mathrm{cm}$ shoot growth, 1.5- to 2-cm shoot growth, $90 \%$ bloom, and < 5\% bloom; Massachusetts, 1-cm shoot growth, $60 \%$ bloom, and fruit set; and Wisconsin, $50 \%$ bloom, $80 \%$ bloom, and 30 days after fruit set.

"Significant by Dunnett's $t$ test at $P \leq 0.05$.

ance may be accounted for in part by the thicker cuticle of mature leaves compared to thin cuticles on new foliage. The apparent lack of any permanent injury would also suggest that clopyralid is primarily transported acropetally to active meristematic tissue and not basipetally to roots and buds (Zollinger et al., 1992).

On the western coast of the United States, there are several perennial weeds (Aster subspictus, Lotus corniculatus, and Trifolium repens) affecting cranberries that begin growing in the spring, well in advance of cranberries. In the midwestern and eastern coastal
United States, the window for control of susceptible perennial weeds (Apios americana Medic., Aster spp., and Solidago graminifolia L.) corresponds to the period after fruit set. The spot use of clopyralid for susceptible weed control in cranberry merits further study.

\section{Literature Cited}

Devlin, R.M. and I.I. Zbiec. 1992. Influence of clopyralid on cranberry fruit growth and development. Proc. Northeastern Weed Sci. Soc. 46:59.

Kloppenburg, D.J. and J.C. Hall. 1990. Penetration of clopyralid and related weak acid herbicides into and through isolated cuticular membranes of Euonymus forunei. Weed Res. 30:431-438.

Patten, K.D., H. Hopen, and D. Riemer. 1991. IR4 PR3882. Clopyracid on cranberries. IR4 Headquarters, Cook College, Rutger Univ., New Bruswick, N.J.

SAS Institute. 1985. SAS user's guide: Statistics, Version 5. SAS Institute, Cary, N.C.

Weed Science Society of America. 1989. Herbicide handbook. Weed Sci. Soc. Amer., Champaign, Ill.

Zollinger, R.K., D. Penner, and J. Kells. 1992. Absorption, translocation, and foliar activity of clopyralid and tribenuron in perennial sowthistle (Sonchus arvensis). Weed Sci. 40:528-533. 